\title{
New Bairdiidae (Ostracoda) from Tulear, Madagascar
}

\author{
ROSALIE F. MADDOCKS \\ Department of Geosciences, University of Houston, Houston, Texas, 77204-5503, U.S.A.
}

\begin{abstract}
The new species Neonesidea thomassini, Aponesidea ifatyensis, and Mydionobairdia tulearensis are described. Their anatomical characters permit emended diagnoses for these poorly known genera and some speculation on relationships of ornate Bairdiidae.
\end{abstract}

\section{INTRODUCTION}

In 1975 Dr. Bernard A. Thomassin (Station Marine d'Endoume et Centre d'Oceanographie, Faculté des Sciences de Marseille, Rue de la Batterie-des-Lions, Marseille 7e) sent me a small collection of podocopid ostracodes collected living in sediments of the outer reef slope off Tulear, Madagascar. The sample proved to contain three new species of Bairdiidae, two of which would require the establishment of new genera as well. Earlier work in the Nosy Be area to the north (Maddocks, 1969) had demonstrated the importance of including soft-part anatomy as well as carapace features in the taxonomic characterization of living Bairdiidae. Only three new genera of Bairdiidae had been proposed in that monograph, although the eventual need for several more had been indicated. Because viable generic concepts must be based on characters shared by a number of included species, it was held that a new genus should not be named until sufficient species are available to delineate its approximate scope and affinities. Accordingly, after dissection and preparation of illustrations, this Tulear material was set aside to await discovery of related species, in the hope that additional species would help clarify the indicated relationships. In particular, it was hoped that males of Triebelina would turn up, to facilitate comparison with that genus and to show whether too much taxonomic weight was being placed on sexual dimorphism of the antenna and fifth limb.

In the intervening years, males of Triebelina have remained as elusive as adherents to these idealistic taxonomic principles. Fortunately, SEM documentation of carapace details has compensated in part for absent soft-part information for many ostracode genera proposed in the last 20 years. Today, the genera to which these Tulear species belong are no longer new, though certainly they remain poorly understood. It now seems appropriate to describe these three species, in order to help validate these generic concepts and to offer some speculations on relationships within this family. I am grateful to Dr. Thomassin for lending this valuable assemblage. The type specimens of the three new species have been deposited in the Muséum National d'Histoire Naturelle, Laboratoire de Zoologie (Arthropodes, Crustacès), 61, Rue de Buffon, 75231 Paris Cedex 05. The illustrated specimens of Aponesidea iliffe $i$ and Mydionobairdia schyroconcha remain in the author's collections at the University of Houston.

\section{SYSTEMATIC DESCRIPTIONS \\ Order PODOCOPIDA Sars, 1866 \\ Superfamily BAIRDIACEA Sars, 1888 \\ Family BAIRDIIDAE Sars, 1888 \\ Genus Neonesidea Maddocks, 1969 \\ Neonesidea thomassini Maddocks, $\mathbf{n}$. sp. \\ (Figs. 1A-T; Pl. 1, figs. 1-10)}

Derivation of name. For Dr. Thomassin, who collected this material.

Types. Holotype male specimen 1194M, MNHN Paris Is 401; paratype specimens $1195-1198,1320-1327$ and undissected specimens, MNHN Paris IS 402-414.

Material. About 160 specimens in alcohol.

Locality. Thomassin sample BT-218, on the reef off Tulear, Madagascar, collected by "scuba-diving dredging using a sporting bag, $10 \mathrm{dm} 3$ of gravelly sediment sampled at $7 \mathrm{~m}$ deep, on the outer reef slope of the If aty reef, in the bottom of a groove of the spurs-and-grooves system, 27/09/1969 (I.B.P. expedition on the outer coral reef slopes of 1969)."

Dimensions. Holotype male specimen 1194M, LVL0.78 mm, LVH $0.59 \mathrm{~mm}, \mathrm{RVL} 0.79 \mathrm{~mm}, \mathrm{RVH} 0.41 \mathrm{~mm}$; paratype female specimen 1326F, LVL $0.80 \mathrm{~mm}$, LVH $0.45 \mathrm{~mm}$, RVL0.83 mm, RVH $0.39 \mathrm{~mm}$. LVL of additional adult male specimens ranges from 0.77 to $0.83 \mathrm{~mm}$; LVL of additional female specimens ranges from 0.80 to $0.85 \mathrm{~mm}$. Females tend to be slightly longer and proportionally higher than males, which is normal dimorphism in Bairdiidae. 
Description. Carapace medium-sized, somewhat compressed, entirely smooth, with well calcified outer layer and thick brown inner chitinous lining, color medium brown with translucent white margins, with large irregular colorless patch in eye region; normal pore canals numerous, simple, of somewhat variable size, with tiny raised rims or no rims; carapace sensillae of moderate size and golden-brown color, simple, thick, tapering; anterior and posterior marginal and near-marginal sensillae longer and thicker; in lateral outline left valve with steeply arched dorsal margin, falling steeply to obscurely rounded, subacute posterior angle; anterior margin truncate, curving slightly to sharp anteroventral angle, ventral margin nearly straight; greatest height located at about one-third length; right valve of complementary shape, with more angulate, sinuous contours; in dorsal view carapace moderately compressed, elongate-ovate in outline, greatest thickness located near midlength; in cross-section greatest thickness located at about one-third height, ventral surface not flattened but curving very steeply; hinge and marginal characters appropriate for Neonesidea, left valve with row of tiny denticles on posteroventral margin, other margins of both valves smooth, without denticles or rough frills; adductor muscle-scar pattern large, with widely spaced linear to wedge-shaped scars, arranged in pattern appropriate for Neonesidea. Antenna with very elongate penultimate podomere; male with fairly short terminal claw with well-developed sigmoid hook, fairly thin accessory claw, and short anterodistal seta; female with thick, smoothly tapering terminal claw, thick accessory claw, and long anterodistal seta. Fifth limb with very short terminal claw and very long anterior setae; vibratory plate of male with two unfeathered setae segregated proximally, female with all four setae widely separated. Sixth and seventh limbs very elongate. Hemipenis elongate with very long, lamellar basal and median segments, short terminal lobe without special features; copulatory tube short, nearly straight. Furca with six setae, seta 2 especially long, setae 5 and 6 very short.

Comparisons. N. thomassini lacks the tear-drop shape, posterior spine, leaf-like posterior setae, and central opaque spot of the typical N. schulzi species-group of Neonesidea. It belongs to the somewhat ill-defined $N$. dinochelata species-group. $\mathrm{N}$. thomassini has about the same size and length-height proportions as the Bahamian species N. dinochelata (Kornicker, 1961) but has more rounded contours, with a less acute posterior angle, less abruptly flattened ventral surface, and tiny posteromarginal spines on the left valve; characters of the hemipenis and furca are distinct but closely comparable. $\mathrm{N}$. thomassini is much larger and more elongate than $\mathrm{N}$. parilihamata Maddocks (1969, Nosy Be) and lacks the distinctive U-cleft antennal claw and the digitate distal lobe of the hemipenis of the latter. It lacks the exaggerated, foreshortened, rhomboidal shape, the terminal spine, and the globose hemipenis of Neonesidea sp. 1 at Nosy Be (Maddocks, 1969). N.thomassini is larger than $N$. ? rara Titterton and Whatley (1988, Solomon Islands) and slightly more elongate in lateral view. It also differs from that species in the nearly straight anteroventral margin, posterior margins, and slightly prolonged, caudate, rounded posterior angle. No other closely similar species have been described.

\section{Genus Aponesidea Maddocks, 1986}

1986 Aponesidea Maddocks in Maddocks and Iliffe: 49 Type species. Aponesidea iliffei Maddocks, 1986 (Bermuda). Other species included:

Aponesidea ifatyensis Maddocks, n. sp.

? Bairdia problematica Hartmann, 1974, p. 254, pl. 23, figs. 170-172 (Angola).

Emended diagnosis. Carapace shape ranges from bairdiid with caudate posterior end to oblong-rhomboidal with truncate posterior. Normal pore canals simple, with narow rims or no rims. Carapace sensillae simple, tapering, of variable size; largest sensillae may be faintly bristled or hirsute near base. Epicuticular ornament of sharp, triangular or toothlike barbs may be present. A few anterior and posterior marginal spines of the left valve may be enlarged and conspicuous.

Remarks. The type species of Aponesidea, A. iliffei Maddocks, 1986, is abundant in marine caves of Bermuda. Bairdia problematica Hartmann, 1974, described from the coast of Angola, may belong here on the basis of carapace characters, but its soft parts are unknown.

Neonesidea? crepidula Titterton and Whatley, 1988 (Solomon Islands), is probably not a species of Aponesidea. Contrary to the description (Titterton and Whatley, 1988, p. 124), its adductor muscle-scar pattern is completely typical of Neonesidea. The finely punctate surface (not visible in pub-

\section{Explanation of Plate 1}

Figs. 1-10. Neonesidea thomassini Maddocks, n. sp. Figs. 1-2, right and left valve exteriors in transmitted light, male specimen 1 194M, MNHN Paris Is 401, X100. Figs. 3-4, right and left valve exteriors in transmitted light, female specimen 1326F, MNHN Paris Is 412, X100. Figs. 5-6, right and left valve exteriors by SEM, male specimen 1327M, MNHN Paris Is 413. X88. Figs 7-8, right and left valve exteriors by SEM, female specimen 1325F, MNHN Paris Is 41 1, X94. Fig.9, smooth surface with rimmed normal pore canals and simple carapace sensillae, specimen $1327 \mathrm{M}$, MNHN Paris Is 413, X1700. Fig. 10, left exterior adductor muscle-scar pattern in transmitted light; note adhering muscle fiber: black dots are normal pore canals; sensillae are visible at left; specimen 1 194M, MNHN Paris Is 401, X200.

Fig. 11. Aponesidea ifatyensis Maddocks, . sp.nov, right exterior adductor muscle-scar pattern in transmitted light; note dissected pattern and adhering muscle fiber; black dots and lines are normal pore canals and sensillae; intervening granular texture results from mosaic fabric of crystallites in carapace wall; specimen $1201 \mathrm{M}$, MNHN Paris Os 415, X200. 

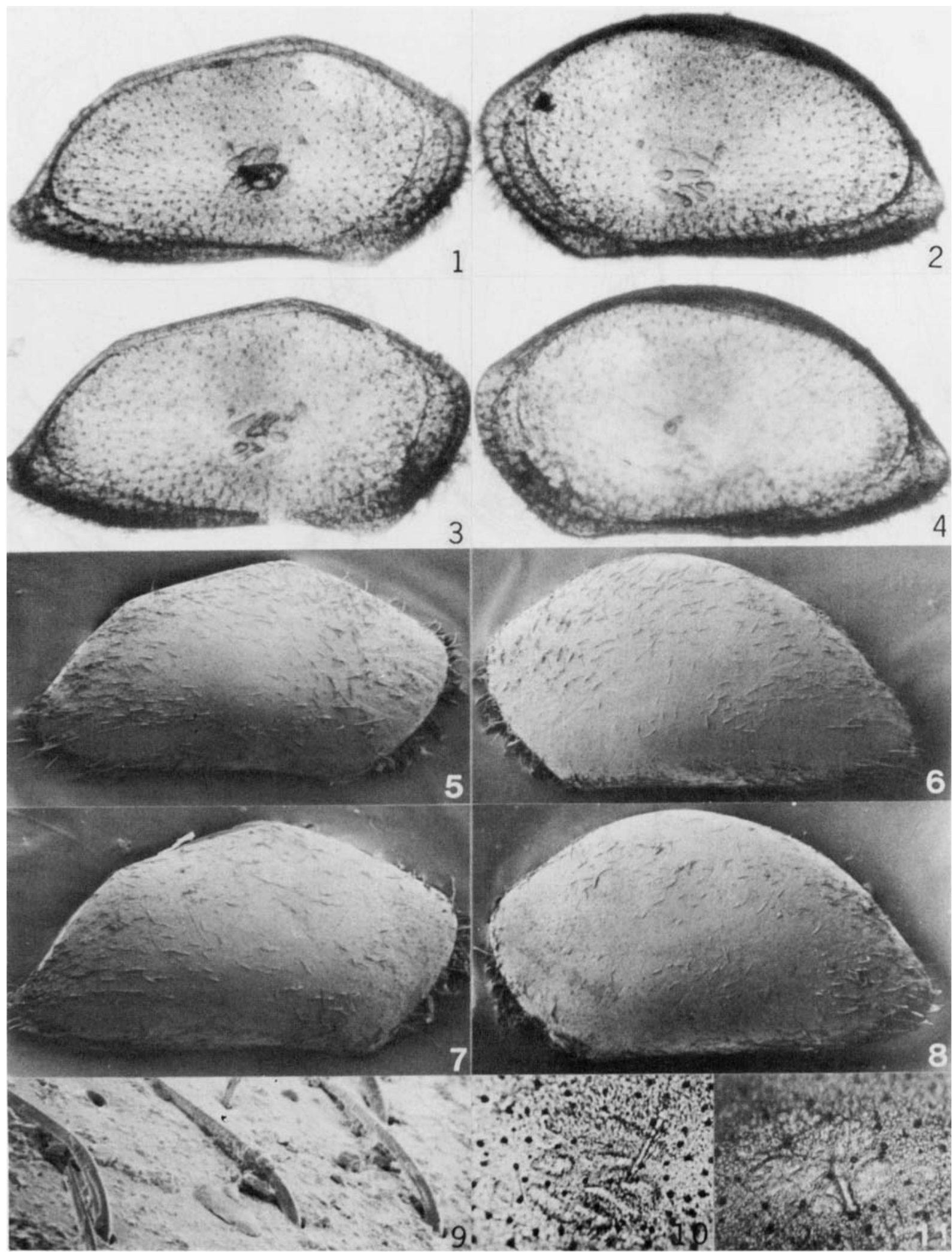


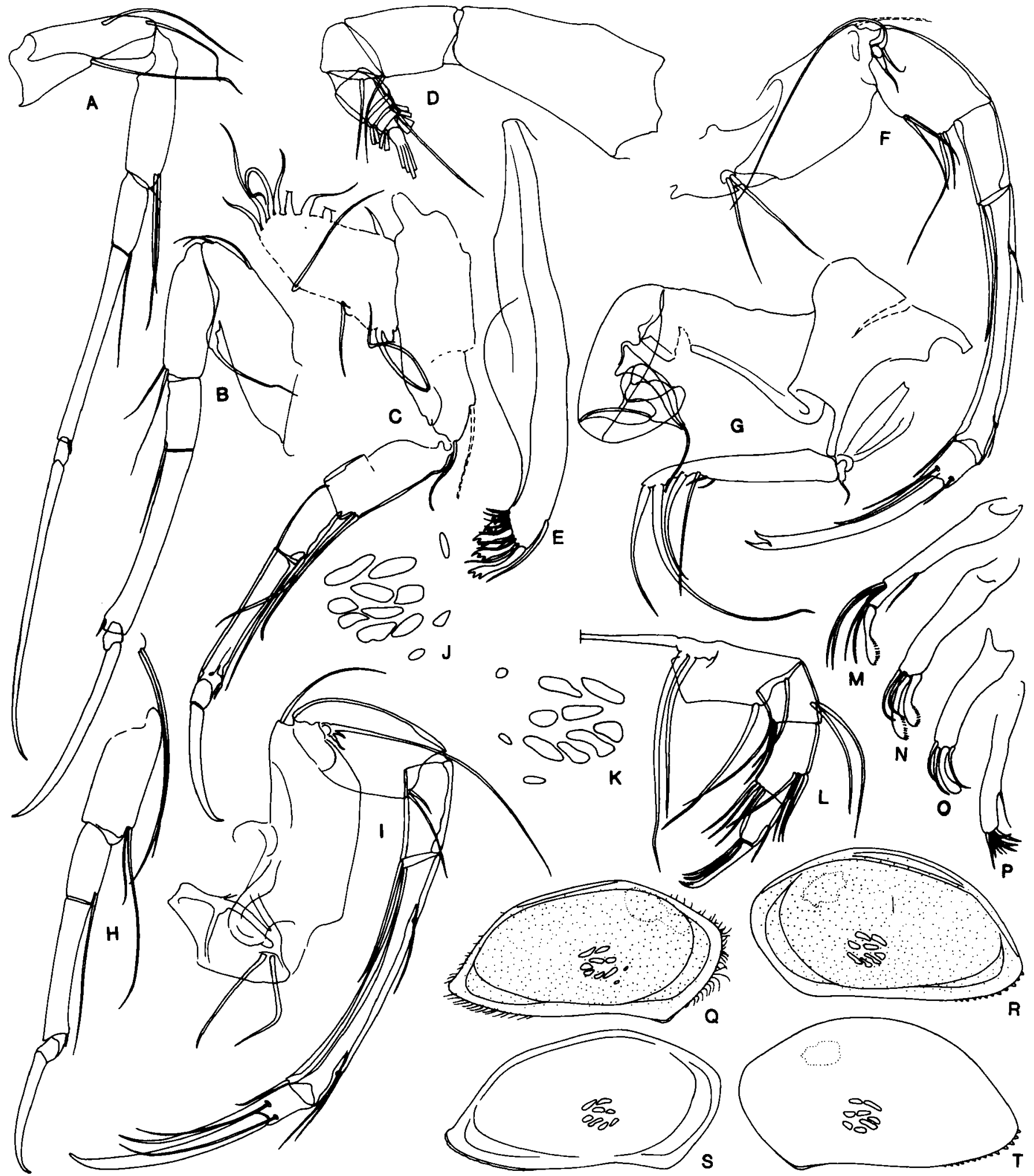

Fig. 1. Neonesidea thomassini Maddocks, sp. nov. A, seventh limb; B, sixth limb; C, H, fifth limb; D, antennule, showing only the bases of the long setae; E, basal podomere of mandible; F, male antennule; G, hemipenis, furca, and postabdominal bristle; I, female antennule; J, K, right and left exterior adductor, frontal, and mandibular muscle scars; L, mandible palp; M-P, palp and masticatory processes of maxillule; Q-T, exteriors of right and left valves as seen in transmitted light. A-B, E-H, J-R, holotype male specimen 1194M, MNHN Paris Is 401; C-D, male specimen 1195M, MNHN Paris Is 402; I, female specimen 1325F, MNHN Paris Is 411; S-T, female specimen 1326F, MNHN Paris Is 412. Magnifications: A-I, L-P, X320; J-K, X155; Q-T, X61. 
lished illustrations), central opaque spot, and absence of anteromarginal denticles further suggest that the assignment to Neonesidea was correct.

The lack of pigmentation and dorsoventral flattening of Aponesidea are appropriate modifications for life in reef crevices or coralline rubble. The occurrence of the new species in sediment dredged on the open reef shows the continuity between reefal, interstitial, cryptic, and subterranean microhabitats.

\section{Aponesidea iliffei Maddocks, 1986}

$$
\text { (Pl. 3, figs. 1-2, 6-9) }
$$

1986 Aponesidea iliffei Maddocks in Maddocks and Iliffe: 50, figs. $8,9$.

Remarks. SEM illustrations are provided here to illustrate the range of carapace proportions of the type species and to show details of normal pore canals, hirsute sensillae, and microornament for comparison with $A$. ifatyensis. By analogy with other Bairdiidae, the smaller, more elongate carapaces may belong to males. The illustrated specimens are empty carapaces from sample 18-II-82 collected by Thomas M. Iliffe in Walsingham Sink Cave, Bermuda (Maddocks and Iliffe, 1986). Their dimensions are as follows: specimen $3102 \mathrm{~W}$, LVL $0.97 \mathrm{~m}$, LVH $0.54 \mathrm{~mm}$, RVL $0.99 \mathrm{~mm}$, RVH $0.52 \mathrm{~mm}$; specimen 3108W, LVL $1.02 \mathrm{~mm}$, LVH $0.55 \mathrm{~mm}$, RVL 1.02 $\mathrm{mm}, \mathrm{RVH} 0.51 \mathrm{~mm}$.

Aponesidea ifatyensis Maddocks, sp. nov. (Figs. 2A-Q; Pl. 1, fig. 11; Pl. 2, figs. 1-5; Pl. 3, figs. 3-5)

Derivation of name. For Ifaty Reef, off Tulear. Types. Holotype male specimen 1201M, MNHN Paris Os 415; paratype specimens $1202 \mathrm{~F}$ and $1566 \mathrm{LV}$, MNHN Paris Os 416417.

Material. Two living specimens, including one male and one female, and one empty left valve.

Locality. In Thomassin sample BT-218 (see above).

Dimensions. Holotype male specimen $1201 \mathrm{M}, \mathrm{RVL} 0.81 \mathrm{~mm}$, RVH $0.37 \mathrm{~mm}, \mathrm{LV}$ not measurable. Female specimen $1202 \mathrm{~F}$ broken, not measurable. Specimen $1566 \mathrm{LV}$, LVL $0.86 \mathrm{~mm}$, LVH $0.43 \mathrm{~mm}$.

Diagnosis. Carapace medium-sized, uniform translucent white with sugary luster, smooth; carapace inflated, ventrally flattened, with greatest thickness located at about one-third of height; in lateral outline left valve rounded-subrhomboidal, with very broadly arched dorsal margin, without anterodorsal or posterodorsal concavity, posterior margin steep and nearly straight, not caudate, ventral margin very gently sinuate and rising somewhat posteriorly, anterior margin sharply beveled, only slightly curved; greatest height located at about one-third length; in dorsal view carapace outline oval, bluntly tapered at anterior and posterior ends, sizes gently curved; three moder- ately large, widely spaced, conical spines located in middle of anterior margin of left valve, with additional very tiny spines above them; three large spines located at posteroventral corner of left valve, with a few smaller ones below; right valve outline complementary, more angulate, right valve margins with broad, striate fringe; normal pore canals numerous, very small, simple, with very narrow rims; carapace sensillae thin, mostly quite short, golden-brown, simple, inconspicuous; carapace surface with fine epicuticular microornament consisting of very tiny, wedge- or arrowhead-shaped raised barbs, aligned in irregular rows outlining polygonal smooth fields; adductor muscle-scar pattern very large, visible externally as transparent spots, arranged in bythocyprid pattern, consisting of four divided, close-spaced, oblong scars, the surfaces of which are very finely etched in a variable, lacy pattern; marginal fused zone moderately wide, vestibules open, radial pore canals inconspicuous.

Antenna dimorphic; male with narrower, longer, very slightly barbed terminal claw, a faintly serrate acessory claw, a short anterodistal seta on last podomere, and two short anterodistal setae on next-to-last podomere; female with shorter, thicker terminal claw, more strongly developed barbs on pectinate accessory claw, long anterodistal seta, and two long setae on next-to-last podomere. Maxillule with relatively short masticatory lobes; lobes 2 and 3 each with one spatulate, blade-shaped seta and three simple setae. Walking legs slender, long, with long, straight terminal claws; vibratory plate of fifth limb with at least one segregated, unfeathered proximal seta and with a very long anterodistal seta on podomere 2; vibratory plate of sixth limb represented by 2 short setae; seventh limb either damaged or without any ventral setae on basal podomere. Furca tapering, with five long distal setae and two very tiny proximal setae, setae 2 and 4 especially long. Male hemipenis compact, short, with broad, irregularly sculptured terminal lobe; very long, unevenly crinkled lamellar process; copulatory tube long, bent in broad U-shape, passing through tunnel in proximal side of terminal lobe.

Comparisons. A. ifatyensis is smaller than $A$. iliffe $i$ and less flamboyant, but it displays all of the characters selected to diagnose the genus Aponesidea (Maddocks and Iliffe, 1986). The carapace of $A$. ifatyensis is lower overall than that of $A$. iliffe $i$, higher posteriorly, oblong rather than bairdian in shape, with bluntly rounded rather than angulate outlines, and has fewer but larger marginal spines. The appendages are somewhat more elongate in podomere proportions and show some small differences in setation, especially of antenna, maxillule, and furca. The hemipenis of $A$. ifatyensis has a broader terminal lobe, longer lamellar attachment, and shorter copulatory tube that is not recurved distally.

Remarks. It is of interest that both species of Aponesidea have similar barbed microornament. This epicuticular microornament of tiny pyramidal or chevronlike barbs (resembling shark teeth) is not common in Bairdiidae, which normally show smooth 
surfaces at high magnifications even in punctate or reticulate species. The polygonal network may correspond to cell margins in the underlying epidermis, as Okada (1981a, 1981b, 1982) has demonstrated for muri of reticulate cytheraceans. Similar barbs, sometimes but not always arranged in this polygonal pattern, have been seen in unpublished SEM photos of Paranesidea sp. 1 (of Maddocks, 1974, Flower Gardens), in some specimens of Paranesidea fracticorallicola Maddocks, 1969 (Nosy Be), and in a punctate-reticulate species of Triebelina (?) (Flower Gardens). More elongate, wispy epicuticular hairs or spinules have been seen in unpublished photos of Paranesidea cratericola Maddocks, 1969 (Nosy Be) and in Bairdoppilata sp. (Maddocks, 1974, Flower Gardens). At present, it appears that these epicuticular microomamental features are too variable in their expression in individuals and too inconsistently distributed among species and genera to be reliable taxonomic characters. However, they ought to be deliberately sought and routinely illustrated, so that general trends may be identified that will assist in characterization of taxa.

Robustly hirsute sensillae are present in Neonesidea anfieldingae Hartmann (1984, pl. 3, fig. 5; Huahine and Rangigoa), Neonesidea dinochelata Kornicker, 1961 (Bahamas), and in Neonesidea arenigena Maddocks, 1969 (Nosy Be) (unpublished photos), compared to which those illustrated here for Aponesidea iliffei (Pl. 3, fig. 2) are much more weakly developed. As is often the case for so-called simple structures, the sensillae of Neonesidea have been illustrated too rarely to determine whether such hirsute structure represents a rare or comon, determinate or erratic, useful or useless taxonomic character.

Genus Mydionobairdia Titterton and Whatley, 1988

1988 Mydionobairdia Titterton and Whatley: 140.

Type species. Triebelina schyroconcha Maddocks, 1969(Nosy
$\mathrm{Be})$.

\section{Other species included:}

Bythocypris spec. of Hartmann (1978, p. 73, pl. 2, figs. 14-16), a single female from Pretty Pool, north of Pt. Hedland, tropical West Australia, in a mud sample among mangroves.

Bythocypris spec. 179 of Hartmann (1981, p. 99, pl. 1, figs. 12, 14), a single female specimen collected in a pool on the north reef of Heron Island among coral rubble, Great Barrier Reef. Triebelina_sp. 1 of Cabioch et al. (1986, p. 25, pl. 7, figs. 8-10); adult and juvenile fossil valves in borehole on Quatemary fringing Ricaudy reef, Noumea, New Caledonia.

Emended diagnosis. Entire carapace surface (not just the dorsal surface) bearing numerous, flat-topped, spinose papillae; intervening areas smooth, without punctae or reticulation; adductor muscle scars close-packed diagonally, much divided, arranged as in Triebelina; normal pore canals simple with narrow raised rims, set flush with surface or elevated as porecones; carapace sensillae of two kinds and sizes, the larger ones simple and tapering, the smaller ones trifurcate.

Male antenna with smoothly tapering terminal claw with smooth tip, not barbed or hooked; accessory fused claw small, faintly serrate; anterodistal seta fairly short. Masticatory processes of maxillule with about four simple, tapering setae, one of which may be larger than others; none spatulate, flattened, or fringed. Furca with five setae; setae 1 and 2 largest, clawlike; setae 3 and 5 fairly short. Hemipenis compact, globose, with hemicircular basal part; terminal lobe very broad, irregularly sculptured;; copulatory tube short, weakly sinuate.

Remarks. Of the known species of Mydionobairdia, $M$. schyroconcha approaches Triebelina most closely in shape, the other species being more nearly quadrangular than rhomboidal in outline. As Keij $(1974,1976)$ and Titterton and Whatley (1988) pointed out, species of Mydionobairdia lack the ribs, the thickened marginal rims, the strong asymmetry, and the punctate-reticulate ornament of Triebelina. The spinose covering of Mydionobairdia has no counterpart in Triebelina.

\section{Explanation of Plate 2}

Figs. 1-5, Aponesidea ifatyensis Maddocks, sp. nov. Fig. 1, dorsal view of whole animal before dissection, in reflected light; note two food balls in gut; male specimen $1201 \mathrm{M}$, MNHN Paris Os 415, X70. Fig. 2, right valve exterior in transmitted light; note striate flange; male specimen $1201 \mathrm{M}$, MNHN Paris Os 415, X70. Fig. 3, left valve exterior in transmitted light, specimen 1566LV, MNHN Paris Os 417, X70. Fig. 4, right valve exterior in reflected light; note grainy luster and darker muscle-scar pattern; male specimen $1201 \mathrm{M}$, MNHN Paris Os 415, X70. Fig. 5, left valve exterior in reflected light, specimen $1566 \mathrm{LV}$, MNHN Paris Os 417, X70.

Figs. 6-17, Mydionohairdia tulearensis Maddocks, sp. nov.. Fig. 6, slightly tilted dorsal view of whole animal before dissection; note two food balls in gut; in reflected light, male specimen $1199 \mathrm{M}$, MNHN Paris Os 418, X100. Figs. 7-8, right and left valve exteriors in transmitted light, note clear muscle scars and damaged dorsal edge of left valve; male specimen $1205 \mathrm{M}$, MNHN Paris Os 421, X100. Figs. 9-10, right and left valve exteriors in reflected light; note coarse granular texture and clear muscle scars; male specimen 1205M, MNHN Paris Os 421, X100. Fig. 11, dorsal views of damaged right and undamaged left valves in reflected light, male specimen 1205M, MNHN Paris Os 421, X100. Fig, 12, slightly tilted right valve exterior to show muscle scars in reflected light, male specimen 1 199M, MNHN Paris Os 418, X 100. Fig. 13, left valve exterior in reflected light, male specimen 1 199M, MNHN Paris Os 418, X100. Fig. 14, exterior of juvenile right valve by SEM, cleaned, with most papillae and sensillae scraped away, specimen 1204J, MNHN Paris Os 420, X130. Fig. 15, left exterior of entire animal before dissection, in reflected light, male specimen 1199M, MNHN Paris Os 418, X100. Fig. 16, exterior of adult right valve by SEM, cleaned, with most sensillae and papillae scraped away, male specimen 1205M, MNHN Paris Os 421, X130. Fig. 17, left exterior muscle-scar pattern in transmitted light; large black dots are normal pore canals, small dots in rows are exterior papillae; male specimen 1199M, MNHN Paris, Os 418, X200. 

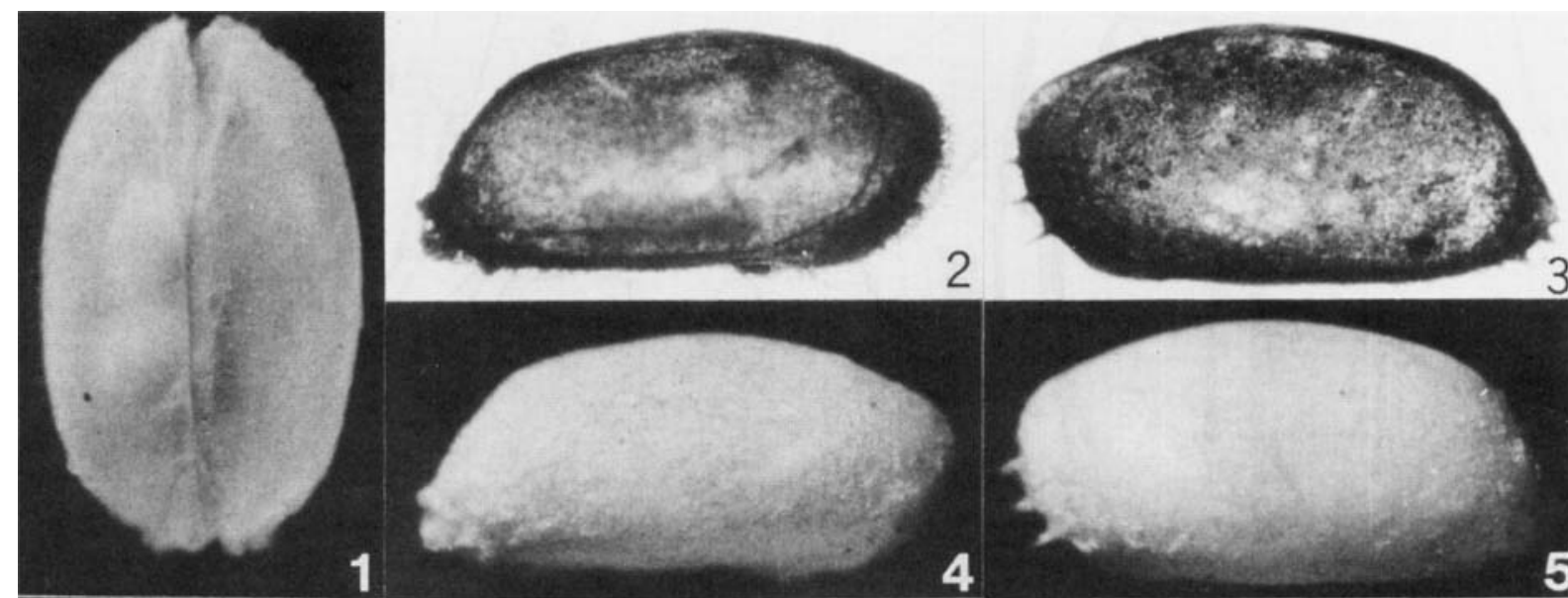

1
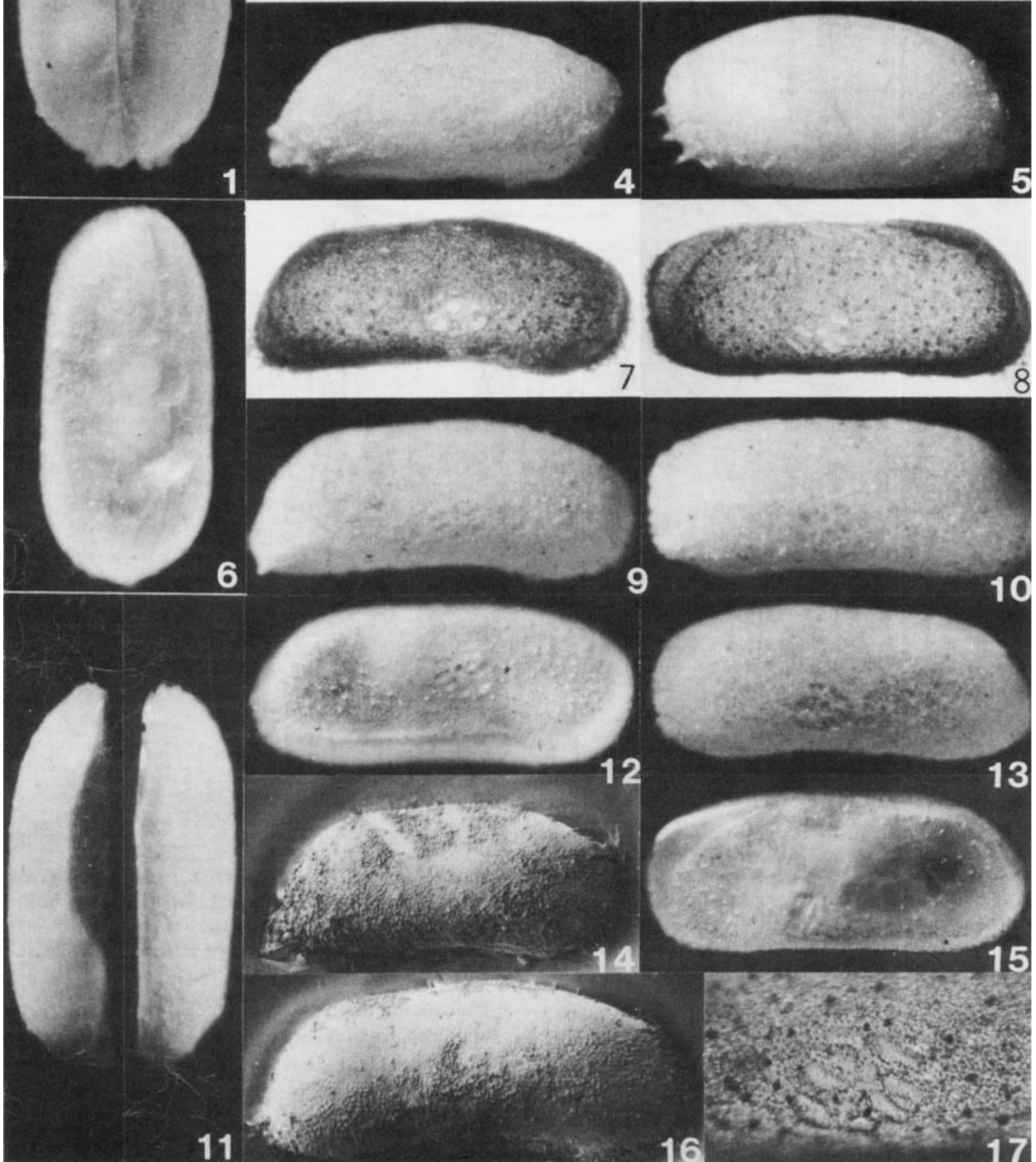

9
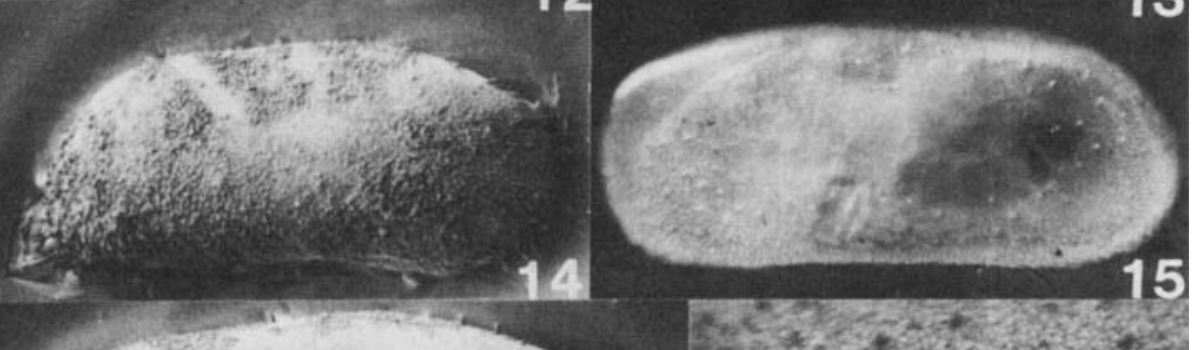

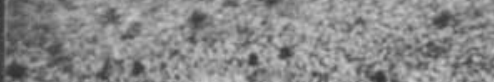
200

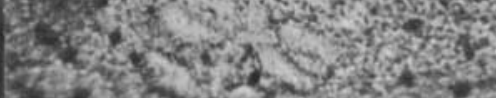
16 


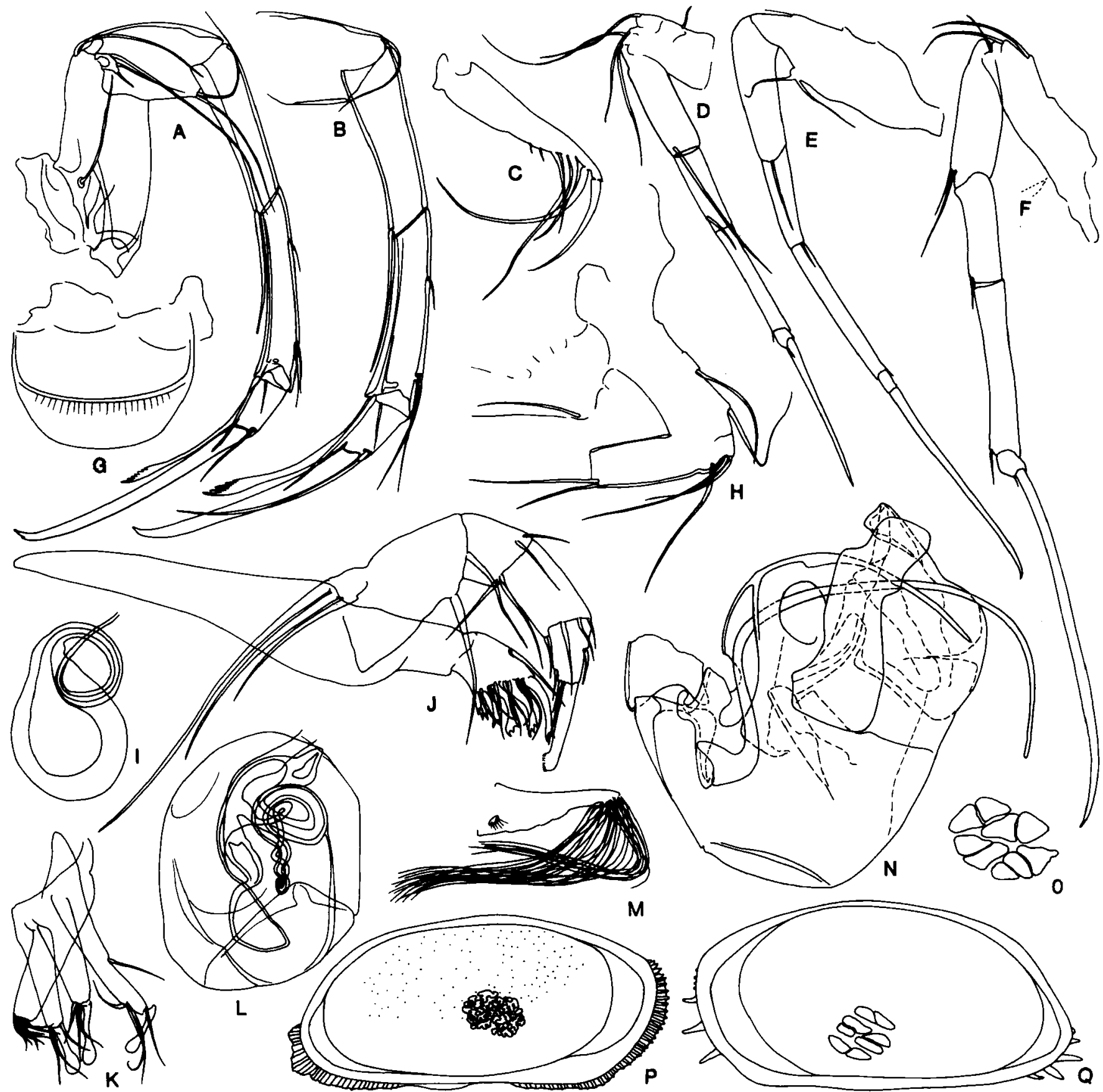

Fig. 2. Aponesidea ifatyensis Maddocks, sp. nov. A, B, male and female antennae; C, furca; D, H, fifth limbs; E, sixth limb; F, seventh limb; G, part of chewing apparatus; I, seminal receptacle; J, mandible; K, palp and masticatory processes of maxillule; L, genital lobe of female; M, brushshaped organ of male; $N$, hemipenis; $O$, right exterior adductor muscle scar pattern;; $P, Q$, exteriors of right and left valves as seen in transmitted light. A, C-F, J-K, M-P, holotype male specimen 1201M, MNHN Paris Os 415; B, G-I, L, female specimen 1202F, MNHN Paris Os 416; Q, specimen 1566LV, MNHN Paris Os 417. Magnifications: A-K, M-N, X320; L, O, X130; P-Q, X77.

That the two genera are closely related is plain, however. Besides the boxy shape, they share many details of pore canals, carapace sensillae, and appendages. Trifurcate sensillae like those of Mydionobairdia are known in Triebelina sertata Triebel, 1948, in Nosy Be, and in a punctate species of Triebelina (?) in the Gulf of Mexico (unpublished pliotos). Regrettably, the absence of knowledge aboutmales in Triebelina and females in Mydionobairdia makes it impossible to compare genitalia and carapace dimorphism. Whereas Triebelina is circumtropical and has a fossil record extending well back into the Tertiary, Mydionobairdia is reported so far only from modern and Quaternary sediments of the western and central Indo-Pacific region.

Titterton and Whatley selected Triebelina schyroconcha Maddocks, 1969, as the type species of Mydionobairdia, and they reported that species to be present in reefal sediments of 
the Solomon Islands and the Java Sea. The only other species they referred to this genus were the two illustrated by Hartmann $(1978,1981)$ from tropical Australia. Somewhat indecisively, they mentioned several other species by name or by implication, stating that some or all of those species could be included if the just-offered diagnosis of Mydionobairdia were to be emended to include punctate forms. They did not present evidence for the inclusion of punctate species, however, nor did they explain their reasons for excluding punctate ornament from the diagnosis just offered. It now seems evident that Mydionobairdia should be restricted to papillate, nonpunctate species. Punctate species, such as the real Bairdia tuberculata Brady, 1880 (Mauritius), Bairdia sp. of Allison and Holden (1971, Clipperton Island), and Bairdia tuberculata Brady of Bold (1966, Colon Harbour, Panama), belong to Triebelina or to a related, unnamed genus rather than to Mydionobairdia. Other species suggested by Titterton and Whatley for admission to Mydionobairdia, if the diagnosis were to be changed to allow punctate ornament, do not appear to be closely related to either Triebelina or Mydionobairdia. Bairdia hanaumaensis Holden (1967, Hawaii) may belong to the N. dinochelata species-group of Neonesidea, if the "fine pits" are really normal pore canals. Bairdia aff. tuberculata Brady of Bold (1966, Colon Harbor, Panama) is reminiscent of Aponesidea.

Hartmann (1981) pointed out that the two Australian specimens are very similar, but that their occurrence in two distinct biogeographic provinces makes it unlikely that they belong to the same species. Minor shape differences are apparent in Hartmann's figures, with the Heron Island specimen being somewhat more elongate, with a sloping, straight dorsal margin, while the Pt. Hedland specimen has a broadly arching dorsal margin and more evenly rounded anterior and posterior margins. The soft parts were not described for either species. The tiny SEM photos show numerous, large, straight, simple setae and a bythocyprid muscle-scar pattern, but the presence of smaller branching setae cannot be established in these photos. The Port Hedland specimen appears to have tiny papillae of uniform size, arranged in fairly regular rows, while the Heron Island specimen has more distantly spaced papillae of variable sizes, less carefully aligned. In both species the papillae seem to be low and granular, rather than flat-topped, volcano-like spines, according to the illustrations of Hartmann. For now, they may be treated as separate species of Mydionobairdia.

There are many uncertainties with respect to size and possible sexual dimorphism of the carapace in species of Mydionobairdia. Fig. 3 summarizes the dimensions published or estimated from illustrations for these and related forms. It will be important to document sexual dimorphism, adult and juvenile development of internal features and external ornament, and small details of normal pores, carapace sensillae, and papillae for these and geographically intermediate populations.

$$
\text { Mydionobairdia schyroconcha (Maddocks, 1969) }
$$

(Pl. 4, figs. 4-5, 10-11)

1969 Triebelina schyroconcha Maddocks: 65, pl. 2, figs. 7-8; figs. $33 \mathrm{~g}-\mathrm{h}$.

1974 ? Triebelina schyroconcha Maddocks: Keij, pl. 1, fig. 7. 1988 Mydionobairdia schyroconcha (Maddocks): Titterton and Whatley, p. 140, pl. 9, figs. 15-19.

Remarks. SEM illustrations of a specimen from Nosy Be are provided here for comparison with other reports and with $M$. tulearensis. Specimen $1314 \mathrm{~W}$ is an empty carapace collected at Nosy Be station 366, in sand among coral patches, depth about $1 \mathrm{~m}$, in Lac du Cratère; LVL $0.62 \mathrm{~mm}$, LVH $0.28 \mathrm{~mm}$, RVL $0.62 \mathrm{~mm}$, RVH $0.27 \mathrm{~mm}$. Specimen 3088LV from Nosy Be 070 from sand with sea grass behind fringing reef at Nosy N'Tangam, depth about $3 \mathrm{~m}$, measures LVL $0.68 \mathrm{~mm}$, LVH $0.37 \mathrm{~mm}$.

The type specimens of M. schyroconcha from Nosy Be were fully adult in breadth of duplicature but distinctly smaller overall than the more recently discovered specimens considered here, although there are no important differences in shape or spinosity. Dimensions of the specimens reported in the Solomon Islands also appear to vary widely.

The specimens reported as Bairdia tuberculata Brady by Brady (1880) from the Admiralty Islands and New Caledonia had tiny tubercles and might have belonged to $M$. schyroconcha. See synonymies provided by Maddocks (1969) and Titterton and Whatley (1988). They are omitted from synonymy here because Brady's specimens ought to be checked, if they still exist, to confirm this identification rather than continuing to repeat it. Cabioch et al. (1986, p. 25) reported similar but larger specimens from New Caledonia as Triebelina $\mathrm{sp} .1$ but insisted on separate species identity.

Keij's (1974) illustration shows a left valve with more elongate proportions and more rounded outline than those cited for M. schyroconcha. This Indonesian form may be a distinct species. Until sexual dimorphism and population variability can be delimited for these populations, it is difficult to evaluate these minor differences.

Mydionobairdia tulearensis Maddocks, sp. nov. (Figs. 3A-V; Pl. 2, figs. 6-17; Pl. 4, figs. 1-3, 6-9)

Derivation of name. For the town of Tulear, Madagascar. Types. Holotype male specimen 1199M, MNHN Paris Os 418; paratype specimens $1200,1204-1206$, MNHN Os 419-422.

Material. Three living specimens, including two males and one juvenile, and two empty valves.

Locality. In Thomassin sample BT-218 (see above).

Dimensions. Holotype male specimen 1199M, LVL $0.58 \mathrm{~mm}$, LVH $0.25 \mathrm{~mm}, \mathrm{RV}$ unmeasurable. Paratype male specimen $1205 \mathrm{M}$, LVL $0.60 \mathrm{~mm}$, LVH $0.25 \mathrm{~mm}$, RVL $0.61 \mathrm{~mm}$, RVH $0.25 \mathrm{~mm}$. Paratype male specimens $1200 \mathrm{M}$ and $1206 \mathrm{M}$ bro- 


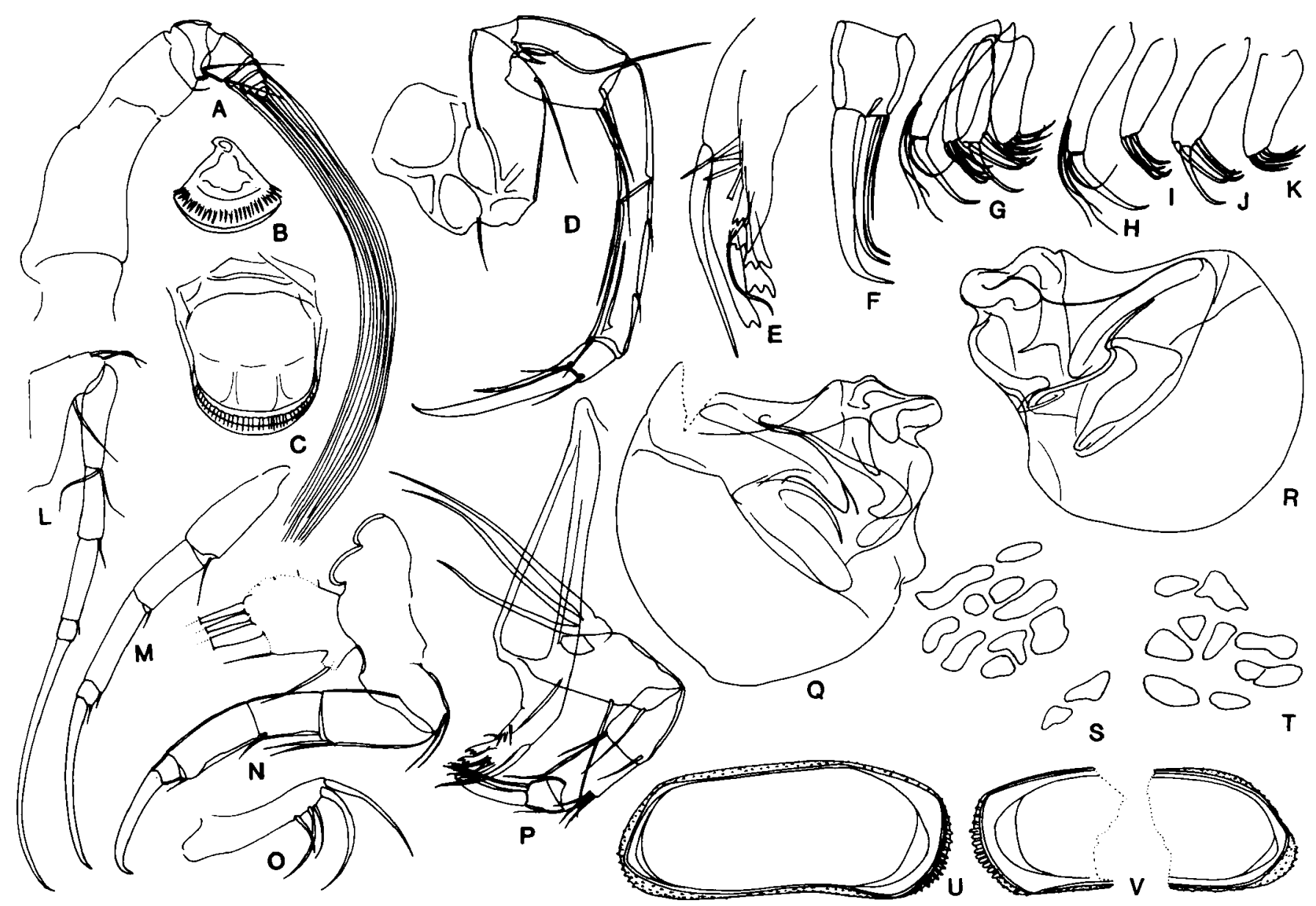

Fig. 3. Mydionobairdia tulearensis Maddocks, sp. nov. A, antennule; B, C, chewing apparatus; D, male antennule; E, masticatory processes of mandible; F, terminal podomere and setae of mandible; G-K, palp and masticatory processes of maxillule; L, seventh limb; M, distal part of sixth limb; N, fifth limb; O, furca; P, mandible; Q-R, both hemipenes; S-T, right and left exterior adductor muscle scars, S includes two mandibular scars; U-V, interiors of left and right valves. A-F, L-R, holotype male specimen 1200M, MNHN Paris Os 419; G-K, U-V, male specimen $1199 \mathrm{M}$, MNHN Paris Os 418; S-T, male specimen 1206M, MNHN Paris Os 422. Magnifications: A-D, G-R, X320; E, X765; S-T, X245; U-V, X77.

\section{Explanation of Plate 3}

Figs. 1-2,6-9, Aponesidea iliffei Maddocks, 1986. Fig. 1, normal pore canals, simple sensillae, and arrowhead-shaped spinules, specimen 3108W, X290. Fig. 2, simple normal pore canals with narrow rims, large and small simple sensillae which may be proximally barbed, and arrowhead-shaped epicuticular microornament, specimen 3102W, X1100. Figs. 6-7, right and left valve exteriors, specimen 3108W, X70. Figs. 8-9, right and left valve exteriors, specimen $3102 \mathrm{~W}, \mathrm{X} 70$. All by SEM.

Figs. 3-5, Aponesidea ifatyensis Maddocks, sp. nov. Fig. 3, simple pores and sensillae, varying in size, with arrowhead-shaped spinules outlining polygonal fields, specimen 1566LV, MNHN Paris Os 417, X750. Fig. 4, simple pores and sensillae, with arrowhead-shaped spinules arranged in polygonal reticulate pattern, specimen 1566LV, MNHN Paris Os 417, X1500. Fig. 5, SEM left valve exterior, $1566 \mathrm{LV}$, MNHN Paris Os 417. X88. All by SEM. 


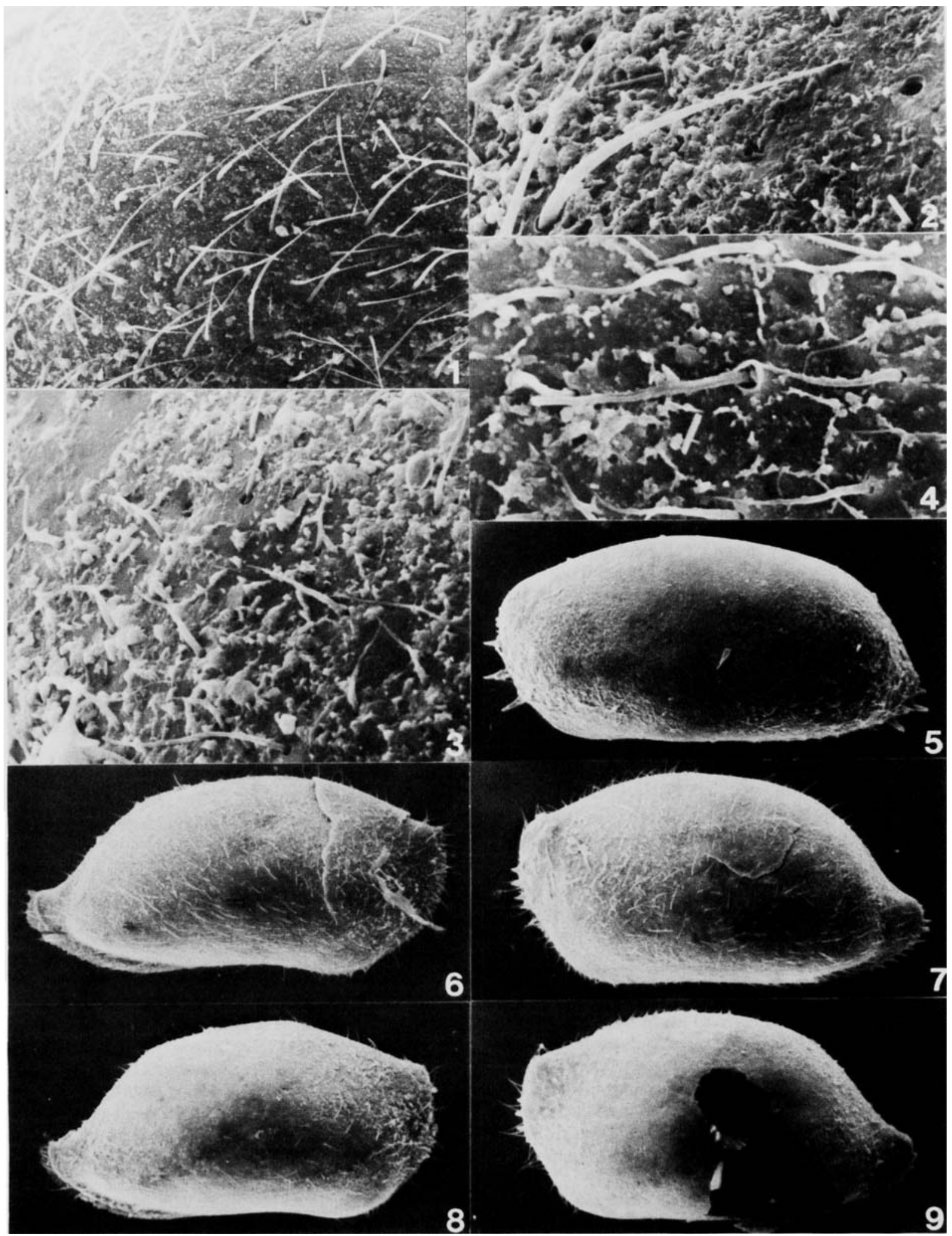




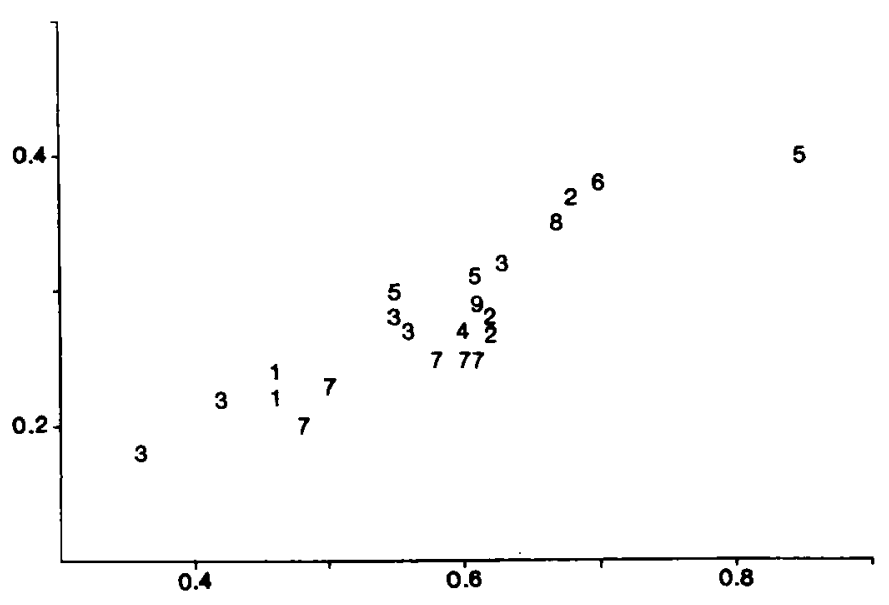

Fig. 4. Dimensions (in mm) published or estimated from illustrations for species of Mydionobairdia and Papillatabairdia. 1, $M$. schyroconcha, Nosy Be 504, specimens USNM 121331, USNM 121332 (types, Maddocks, 1969); 2, M. schyroconcha, Nosy Be 366 and 070 , specimens $1314 \mathrm{~W}$ and $3088 \mathrm{LV} ; 3, M$. schyroconcha, Solomon Islands (Titterton and Whatley, 1988); 4, M. sp., Irian, (Keij, 1974); 5, M. sp., New Caledonia (Cabioch et al., 1986); 6, M. sp., Port Hedland (Hartmann, 1978); 7, M. tulearensis, specimens 1199M, 1205M, 1204J (MNHN Paris 418, 421, 420); 8, $P$. dentata, Brisbane Water (Bentley, 1981); 9, $P$. cf. dentata, Port Hedland (Howe and McKenzie, 1989). Neither dimensions nor magnifications were reported for $M$. sp., Heron Island (Hartmann, 1981). Both left and right valves are plotted. Right valves are slightly lower but about the same length as left valves, so their inclusion increases the vertical but not horizontal scatter. Some workers have identified smaller specimens as juveniles, but at least some of these smaller specimens have adult marginal characters. The discrepancies show the need for more careful discrimination of species and for recognizing sexual dimorphism within species.

ken, not measurable. Juvenile specimen 1204J, LVL $0.50 \mathrm{~mm}$, LVH $0.23 \mathrm{~mm}$, RVL $0.48 \mathrm{~mm}$, RVH $0.20 \mathrm{~mm}$.

Diagnosis. Carapace small, elongate, boxy, thick-walled but brittle, translucent white in color; under low magnification exterior appears smooth with very finely granular luster or texture, with an almost irridescent, plushlike, matte finish; under high magnification and SEM the surface is densely covered all over by rows of tiny, tapering, spinose, flat-topped papillae; tiny spines may be present around valve margins, only slightly larger than those on exterior surface; normal pore canals small, simple holes with narrow but distinct raised rims, set flush with surface, not raised as pore-cones; two sizes of normal pore canals and sensillae are evident; the larger canals have large, simple, tapering sensillae; the smaller canals have thinner, shorter three-branched sensillae; longer, thicker, simple sensillae located around anterior and posteroventral margins; lateral outline of left valve nearly rectangular, very elongate, with broadly rounded, slightly trunctate anterior margin, slightly sloping anterodorsal and posterodorsal margins, very long, straight central dorsal margin, broadly rounded posterior margin, slightly upswung posteroventral margin, and slightly concave ventral margin; shape of right valve complementary, slightly more angular; carapace very elongate in dorsal outline, with broadly rounded anterior and slightly truncate posterior ends, and straight, parallel sides; venter flattened; marginal fused zone broad, vestibules shallow, radial pore canals inconspicuous; adductor muscle scars very large, transparent, erratically subdivided, arranged in diagonally elongated pattern similar to that of Triebelina.

Antennule compact with condensed terminal podomeres and fairly long terminal setae. Male antenna of fairly robust proportions with simple, broad, tapering, curved terminal claw, without terminal hook or barbs; accessory fused seta fairly thin, with faint distal barbs; anterodistal seta moderately short. Masticatory processes of maxillule with simple tapering setae, none flattened, spatulate, fringed or otherwise differentiated, although one may be thicker than the others. Fifth limb robust with short terminal claw; vibratory plate damaged, appears to have at least two and perhaps more segregated, featherless proximal setae. Furca with only five setae, setae 1 and 2 thick and nearly equally long, setae 3 and 5 moderately short, seta 4 a little longer; no trace of setae 6 and 7. Hemipenis large, compact, globose, with hemispherical basal capsule; terminal lobe broad, irregularly scuptured into convolute ridges; copulatory rod fairly short, irregularly sinuate, not passing through any arch or tunnel.

\section{Explanation of Plate 4}

Figs. 1-3, 6-9, Mydionobairdia tulearensis Maddocks,Sp. nov. Fig. 1, rows of uniform papillae, large and small rimmed pores, simple sensillae of varying sizes, and smaller trifurcate sensillae, male specimen 1200M, MNHN Paris Os 419, X1420. Fig. 2, rows of papillae, rimmed pores, and simple and trifurcate sensillae, almost buried in thick layer of debris, male specimen 1199M, MNHN Paris Os 418, X1650. Fig. 3, enlargement of part of fig. 1, showing large and small rimmed pores with bases of simple and trifurcate sensillae, male specimen 1200M, MNHN Paris Os 419, X3600. Fig. 6, dorsal views of right and left valves, male specimen 1200M, MNHN Paris Os 419, X130. Fig. 7, exterior of left valve, not cleaned, papillae covered in places by thick blanket of debris, holotype male specimen 1199M, MNHN Paris Os 418, X130. Figs. 8-9, exteriors of right and left valves, not cleaned, with densely spaced rows of uniform papillae; smooth fields are the smothering blanket of debris; male specimen $1200 \mathrm{M}$, MNHN Paris Os 419, X130. All by SEM.

Figs. 4-5, 10-11, Mydionobairdia schyroconcha Maddocks, 1969. Fig. 4, one flat-topped, volcano-like papilla with abraded tip, showing porous endocuticle (?), and base of trifurcate seta, specimen $1314 \mathrm{~W}, \mathrm{X} 4100$. Fig. 4, tilted lateral view showing flat-topped, volcano-like papillae plus elevated pore-cones of nearly equal size with simple sensillae, specimen 1314W, X950. Figs. 10-11, right and left valve exteriors showing shaggy coat of densely packed spines and pore-cones of varying sizes, rising above thick blanket of debris, specimen 1314W, X125. 


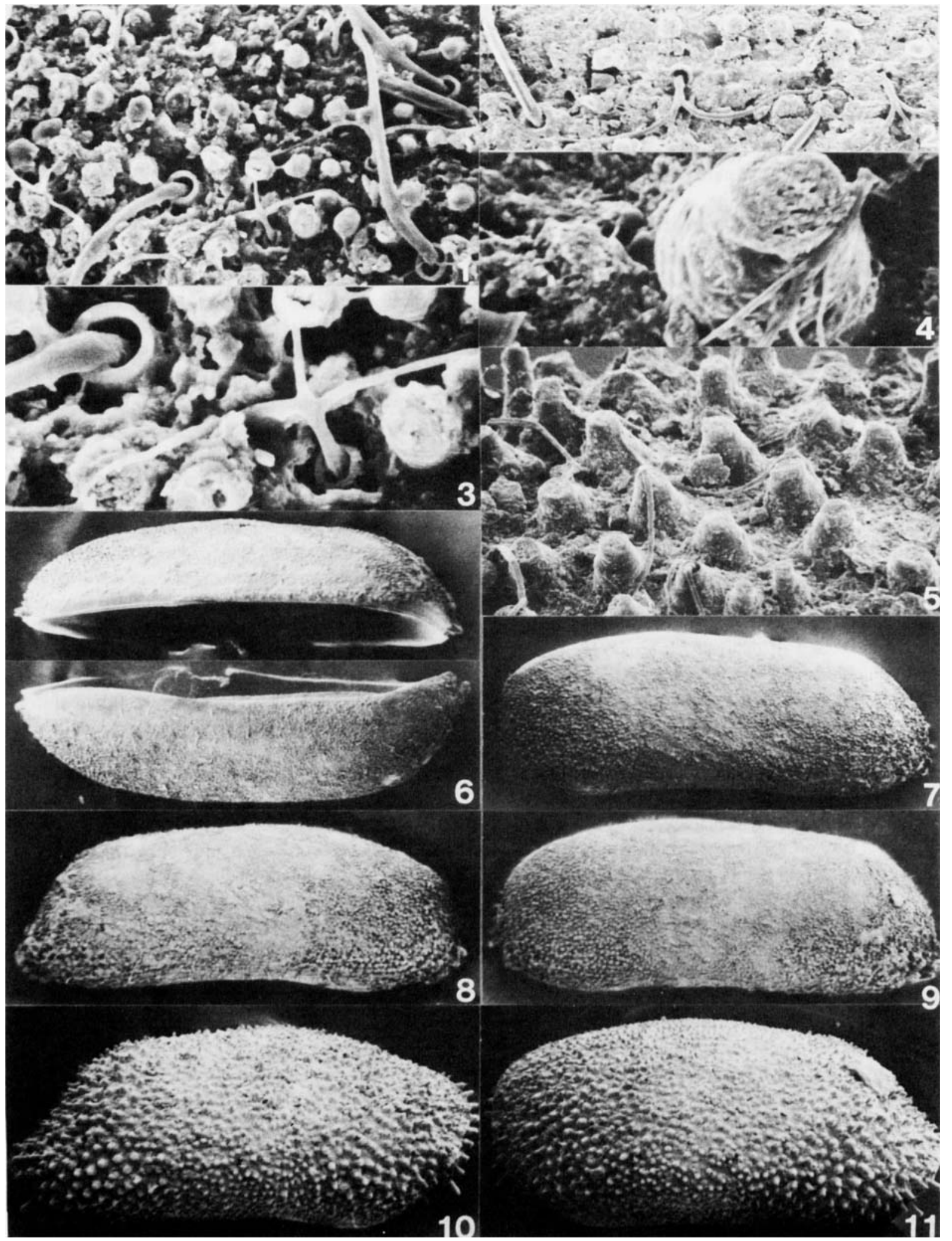


Comparisons. M.tulearensis is longer than or about the same length as $M$. schyroconcha but has much more elongate proportions, more rectilinear outlines, oblong rather than bairdian shape, and much smaller, shorter, more numerous papillae. $M$. schyroconcha is more caudate posteriorly and more abruptly truncate or beveled anteriorly, giving it more nearly subrhomboidal to elongate-hexagonal outlines in lateral view, whereas $\mathbf{M}$. tulearensis is more quadrilateral in outline. In $\mathbf{M}$. schyroconcha a few of the normal pores are built up as volcanoshaped pore-cones, almost as large as some of the smaller papillae, whereas all pores in $M$. tulearensis are set flush with the surface. In $M$. schyroconcha the papillae are much larger REFERENCES

than in M. tulearensis, easily visible under low magnifications, and those on the anteroventral and posteroventral flanks and margins are longer than others elsewhere, giving the carapace a shaggy appearance. M. tulearensis has a more regularly linear arrangement of papillae, and the papillae are more consistently flat-topped than is the case in $M$. schyroconcha. Neither species has any punctae or reticulate ornament.

$M$. tulearensis is smaller, more elongate, and more quadrangular in shape than either of the tropical Australian species figured by Hartmann, 1978, 1981), which have more equant proportions and more rounded outlines in lateral view. The Australian species appear to have low, granular papillae rather than flat-topped, volcano-like spines.

Remarks. These specimens, though living when collected, were covered with a thick coat of debris. Ultrasonic cleaning in detergent and water did not remove this slime, although it broke some valves. An effort was made to remove this coating by gentle stroking with a brush and fine needle, with the valve immersed in water and detergent or in glycerine. This successfully removed not only the slime but the papillae and setae! The tenacity and completeness of this coating, which was absent from the other two species in these samples, suggests that it serves some protective function in life or at least does no harm. One may even speculate that the purpose of the rows of papillae is to encourage or anchor this blanket of debris. This debris-trapping slime is probably a bacterial-fungal overgrowth, rather than a secretion of the ostracode. In Nosy Be, $T$. schyroconcha has the same coating. In both species most papillae are flat-topped, exposing porous endocuticle, and exocuticle appears to be missing or abraded from the tips of the papillae. The ease with which the papillae may be scraped away to produce a smooth surface with low, rounded elevations suggests that this papillate ornament may be weakly calcified. Further, it is possible that abrasion after death could have the same effect, producing an undulating exterior like that of Papillatabairdia dentata from the spiny carpet of Mydionobairdia.

Genus Papillatabairdia Bentley, 1981

1981 Papillatabairdia Bentley: 59.
Type species. Papillatabairdia dentata Bentley, 1981, p. 59, figs. 2-7.

\section{Other species included:}

1989 Papillatabairdia cf. dentata Bentley: Howe and McKenzie, p. 6 , figs. $42,44$.

? 1969 Paranesidea ? cheroconcha Maddocks: 51, fig. 27c, d,i.

Remarks. In their diagnosis of Mydionobairdia , Titterton and Whatley (1988) carefully distinguished this genus from Papillatabairdia, which is reniform in shape with rounded outlines and is covered with low, hemispherical elevations. According to Bentley's illustrations, Papillatabairdia dentata lacks the boxy shape, flattened venter, thickened rims, asymmetry, and punctatereticulate ornament of Triebelina. The low, hemispherical mounds do not rise high enough above the surface, except near the margin, to resemble the flat-topped papillae of Mydionobairdia. The wellpreserved, large, simple sensillae (visible in Bentley's fig. 3) indicate that the surface is fresh and well conserved (not abraded or scraped, as in the cleaned specimens of $M$. tulearensis in PI. 2 , figs. 14, 16), and that the low granular texture is the original microornament. No trifurcate sensillae are visible.

In spite of its name, Papillatabairdia dentata Bentley, 1981, might possibly not be a bairdiacean. Its rather large size, thinwalled, inflated, smoothly curving, symmetrical carapace, sturdy simple sensillae, adont hinge, and incompletely illustrated adductor-muscle scars suggest a species of freshwater Cyprididae. Similar low granular or mounded ornament can occur in freshwatercypridids, for example in species of Newnhamia. Bentley found empty carapaces and valves of this species in muddy sand (depth not stated) of Brisbane Water, a small estuary near Sydney in southeastern Australia, some 10 degrees south of the Tropic of Capricorn. This is an unlikely setting for ornate Bairdiidae but is one to which freshwater cypridids would easily be transported. The accompanying fauna of 51 species (Bentley, 1988) includes no other ornate Bairdiidae and is not a reefal association.

Howe and McKenzie (1989) found empty valves of Papillatabairdia cf. dentata in a sample from an oyster bed next to swimming pool, Port Hedland, Western Australia, associated with a normal nearshore marine fauna including other species of Bairdiidae. The SEM photos (Figs. 42, 44) show a corroded surface from which exocuticle has been removed (?), in which the papillae stand as low, dense mounds of solid calcite in contrast to the porous, microgranular texture of the surrounding endocuticle. Perhaps in life these mounds formed the inner cores of spinose extensions of epicuticle. Microstructural analyses of the wall fabric might establish whether these mounds are homologous with the spinose papillae of Mydionobairdia and whether either is homologous with the barbed microornament reported in some smooth bairdians (see above).

Papillatabairdia may be related to the puzzling species Paranesidea? cheroconcha, described from the continental shelf of Mozambique by Maddocks (1969, p. 51, figs. 27c, d, i). The latter is not Paranesidea, of course, and is much larger than any species discussed here (LVL $1.03 \mathrm{~mm}, \mathrm{LVH} 0.67 \mathrm{~mm}$; Maddocks, 
1969, p. 54). Features of resemblance include the bythocyprid lateral outline, spinose microornament, "posterior siphonate indentation of selvage," and the prominent raised fulcral point. The distal antennal claws of the female (Maddocks, 1969, figs. 17i) are bairdiid in structure but not barbed or serrate like those of Triebelina,. Although the reniform carapace outline is reminiscent of Bythocypris, the antennal claws lack the specialized features of both Bythocyprididae and Pussellidae, nor have ornate exteriors been reported for other species of those two families.

\section{Manuscript received February 1990. Revised manuscript accepted July 1990.}

Allison, E. C., and J. C. Holden, 1971. Recent ostracodes from Clipperton Island, eastern tropical Pacific. Transactions of the San Diego Society of Natural History, 16 (7) 165-214.

Bentley, Christopher, 1981. Papillatabairdia, a new ostracod genus from Brisbane Water, New South Wales. Journal and Proceedings, Royal Society of New South Wales, 114, 59-61.

Bentley, Christopher, 1988. Podocopid ostracods of Brisbane Water, near Sydney, South-Eastern Australia, p. 439-448. In, Tetsuro Hanai, Noriyuki Ikeya, and Kunihiro Ishizaki, eds., Evolutionary Biology of Ostracoda, Its Fundamentals and Applications, Elsevier Publishing Company, Amsterdam

-Oxford-New York-Tokyo, $1356 \mathrm{p}$.

Bold, W. A. van den, 1966. Ostracoda from Colon Harbour,

Panama. Caribhean Journal of Science, 6, 43-64.

Brady, G. S., 1880. Report on the Ostracoda dredged by H.M.S. Challenger during the years 1873-1876. Report of the Scientific Results of the Voyage of H.M. S. Challenger, Zoology, 1 (3), I-184.

Cabioch, Guy, Roger Anglada, and J.-F. Babinot, 1986.

Microfaunes et paléoenvironnements des récifs frangeants quaternaires de Mamié et Ricaudy (Nouvelle-Calédonie). Cahiers de Micropalóntologie, n. s., 1, 5-36,

Hartmann, Gerd, 1974. Zur Kenntnis des Eulitorals der

afrikanischen Westküste zwischen Angola und Kap der Guten Hoffnung und der afrikanischen Ostküste von Südafrika und Mocambique unter besonderer Berücksichtigung der Polychaeten und Ostracoden. Teil III. Die Ostracoden des Untersuchungsgebiets. Mitteilungen aus dem Hamburgischen Zoologischen Museum und Institut, 69, 229-520.

Hartmann, Gerd, 1978. Teil 1, Die Ostracoden der Ordnung

Podocopida G. W. Müller 1894 der tropisch-subtropischen Westküste Australiens (zwischen Derby im Norden und Perth im Süden), p. 65219. In, Hartmann-Schröder, Gesa, and Gerd Hartmann, Zur Kenntnis des Eulitorals der australischen Küsten unter besonderer Berücksichtigung der Polychaeten und Ostracoden. Mitteilungen aus dem Hamburgischen Zoologischen Museum und Institut, 75, 63-

219.

Hartmann, Gerd, 1981. Teil 7. Die Ostracoden der Ordnung

Podocopida G. W. Müller, 1894 der subtropisch-tropischen Ostküste Australiens (zwischen Eden im Süden und Heron-Island im Norden). Mitteilungen aus dem Hamburgischen Zoologischen Museum und Institut, 78, 97-149.

Hartmann, Gerd, 1984. Zur Kenntnis der Ostracoden der

Polynesischen Inseln Huahiné (Gesellschaftsinseln) und Rangiroa
(Tuamotu-Inseln). Mitteilungen aus dem Hamburgischen Zoologischen Museum und Institut, 81, 117-169.

Holden, J. C., 1967. Late Cenozoic ostracodes from the draowned terraces in the Hawaiian Islands. Pacific Science, 21, 1-50. Holden, J. C., 1976. Late Cenozoic Ostracoda from Midway Island drill holes. U. S. Geological Survey, Professional Paper 680F, $1-43$.

Howe, H. V., and K. G. McKenzie, 1989. Recent marine

Ostracoda (Crustacea) from Darwin and north-western Australia.

Northern Territory Museum of Arts and Sciences, Monograph Series, No. 3, 1-50.

Keij, A. J., 1974. Review of the Indopacific species of Triebelina

(Ostracoda). Koninklijke Nederlandse Akademie van Wetenschappen,

Amsterdam, Proceedings, series B, 77, 345-358.

Keij, A. J., 1976. Note on Havanardia and Triebelina species

(Ostracoda). Koninklijke Nederlandse Akademie van Wetenschappen, Amsterdam, Proceedings, series B, 79, 36-44.

Kornicker, L. S., 1961. Ecology and taxonomy of recent

Bairdiinae (Ostracoda). Micropaleontology, 7, 55-70.

Maddocks, Rosalie F., 1969. Revision of recent Bairdiidae (Ostracoda). United States National Museum Bulletin, 295, 1-126.

Maddocks, Rosalie F., 1974. Ostracodes, p. 200-215. In, T. J.

Bright and L. H. Pequegnat, eds., Biota of the West Flower Garden Bank, Gulf Publishing Company, Houston.

Maddocks, Rosalie F., and Thomas M. Iliffe, 1986. Podocopid

Ostracoda of Bermudian caves. Stygologia, 1, 16-76.

Okada, Yutaka, 1981a. Development of cell arrangement in ostracod carapaces. Paleobiology, 7, 276-280.

Okada, Yutaka, $1981 \mathrm{~b}$. Structure and cuticle formation of thereticulated carapace of the ostracode Bicornucythere bisanensis. Lethaia, 15, 85-101.

Okada, Yutaka, 1982. Ultrastructure and pattern of the cara pace of Bicornucythere bisanensis (Ostracoda, Crustacea), p. 229255. In, Tetsuro Hanai, ed., Studies on Japanese Ostracoda, The University of Tokyo, University Museum Bulletin 20, 1-272.

Sars, G. O., 1866. Oversigt af Norges marine ostracoder.

Norske Videnskabsselskabet, forhandlinger 1865, Christiania, Norway, $130 \mathrm{p}$.

Sars, G. O., 1888. Nye Bidrag til Kundskaben om Middlehavets

Invertebratfauna. 4. Ostracoda Mediterranea. Archiv for Mathematik og Naturvidenskab Oslo, 12, 173-324.

Titterton, Rosemary, and Robin Whatley, 1988. Recent

Bairdinae (Crustacea, Ostracoda) from the Solomon Islands. Journal of Micropalaeontology, 7, 11-142.

Triebel, Erich, 1948. Zur Kenntnis der Ostracoden-Gattung

Triebelina. Senckenbergiana, 19, 17-22. 